\title{
CHALLENGES PRESIDENCY ELECTION IN THE NEW EMERGING DEMOCRACTIC COUNTRIES: A CASE STUDY OF INDONESIAN SYSTEM
}

\author{
Paisol Burlian \\ University Muhamdiyah Palembang, INDONESIA \\ burlianpaisol@yahoo.co.id
}

\begin{abstract}
Democratic countries transformed the Athenian ideal into national culture on the dynamic basis fenomenon. As a case study for Contitutional Law, this paper sought the formation of a democary system of Indonesia, which was place of hundred traditional kingdoms before august 1945 proclamation. It meets a great variety of challanges from Soekarno era untill now. A research with historical approach documentary was done to map out two contrast opinions about Presidential System of Republic of Indonesia. Using the content analysis, the results showed that the mechanism of election of head of state in Indonesia theoretically and empirically has happened with two models. First is by way of the state's highest institution, the People's Consultative Assembly. Second is by way of the direct election from people who have the right to vote. Law interpretations and political conditions made Indonesia had shifted from the 1945 Guided Democracy during Soekarno's Era, to the 1968 Pancasila Democarcy of Soeharto, the 1998 Reformation, and the 2004 Direct Democacypopular vote in SB Yudoyono and Joko Widodo Presindential elections.
\end{abstract}

Keywords: Contritutional law; presidential election; vote; representative model

\section{Background}

The ideal of Athen Democaracy of the 5th century BC, a direct democracy, a form of government in which the people right to make political decisions has made the new emerging countries adopted it to keep the national integration and Human Rights. There are variety of democratic terms, some are called constitutional democracies, parliamentary democracy, Indonesian Guided Democracy, Pancasila democracy, people's democracy, Soviet democracy, national democracy.According to a study conducted by UNESCO in 1949, "it is possible for the first time in the history of democracy to be declared the best and natural name for all political and social systems of organization championed by influential supporters". The idea of democracy is ambiguous or has a two-dimensional meaning, which at least there is ambiguity or stipulation "of institutions or ways of implementing ideas, or of the cultural and historical circumstances affecting the term, ideas and practices of democracy " (UNESCO, 1949). Thus, two most important groups of schools are Constitutional Democracy and democracy of communism. Both groups of early democracies came from Europe, but after the Second World War there were emerged several new countries in Asia, such as India, Pakistan, the Philippines, and Indonesia, which aspired to constitutional democracy, Types of government and lifestyles in these countries. On the other hand there are new countries in Asia based on the principles of communism, such as Rep of China Peoples, North Korea, and so forth.

In Indonesia democracy adoption was based on its ideology Pancasila, which is still in the stage of development and having many interpretations and views. Indonesian's democracy, in some of the principal values, meets constitutional democracy model in the 1945 Constitution. In addition, Indonesian's Constitution explicitly mentions the two principles that embody the text, and which is stated in the explanation of State Government System: Firstly, Indonesia is a State based on the law (Rechtsstaat). The State of Indonesia is based on the Law (Rechtsstaat), not based on the power (Machtsstaat). And the second is the Constitutional System of Government based on the Constitutional System (the Basic Law), not the Absolutism (unlimited power). Based on the two terms "(Rechtsstaat)", and "constitutional system", it is clear that the democracy underlying the 1945 Constitution is constitutional democracy. In addition, the typical feature of Indonesian democracy is 
"people based on wisdom in deliberative representation", contained in the Preamble of the Constitution.

After the suppression of Communist Party rebellion (G. $30 \mathrm{~S}$ of The Communist Party of Indonesia) in 1965 , it is clear that the goal is constitutional democracy, but it cannot be denied that in the period of democracy, Guided Democracy is affected by some community concepts due to Communist's cleverness to smuggle concepts of the mind of communism into political life in pre-communist rebellion time. Therefore, it is necessary to clarify our own thoughts and to look at two very different mainstream schools of thought, often contradicting and confronting each other, namely constitutional democracy and "democracy" based on Markxism-Leninism where the fundamentally different is that constitutional democracy aspires to a government restricted to its power of a State of Law subject to the Rule of Law. On the other hand, "Democracy" based on communism aspires to government which cannot be restricted to its power, and which is totalitarian.

\section{Theoretical framework: Presidency Election}

State as political actors clearly has a potentially wide-ranging potential in society (Anderson 1987:17). The state as a tool of society has the power to regulate human relations and the symptoms of power in society (Budiardjo 1978: 22). The state with its sovereignty is a powerful tool for the advancement of humanity, thus representing an important public institution to help people achieve better life goals (Singh 1986, pp. 86). Another view defined that the state as a formal institution established to serve the human needs that have developed throughout the social "evolutionary" history (Rodee, et al., 1983). According to Durkheim, the state is the organ of social thought which acts as an organ of communication with other societies, in contrast to Weber's view with three principal elements, namely administrative staff (regularized), "claims" of monopoly control by violence and monopoly over the region Certain territories (Giddens 1993: 78). While Giddens defined the state as a political apparatus, which governs a particular territory, has the authority supported by a legal system and the ability to use force to enforce its wisdom (Giddens 1993: 79).

According to Adam Smith, the duty of the state is to protect the people from the violence of any institution, the injustice of other societies and the maintenance of public works (Stepan 1978:.22), while the functions of other countries are foreign security, internal Order, justice, public welfare and freedom (Budiardo 1978: 79). Therefore, the state needs the means to achieve this function, namely the police and military forces, the independent judiciary, the obedient civil servants to the state as well as the honest financial administration and monopoly of financial matters. Indonesia as a democratic country must be in accordance with the provisions stated in the 1945 Constitution. The democratic characteristic demanded according to the 1945 Constitution is that all state institutions having power must be elected either directly or indirectly. The institutions of the state according to the 1945 Constitution can be distinguished from the active institutions, namely the executive institutions (President and Vice President) and the legislative and passive state institutions, namely the judicial / judicial authorities (Supreme Court, Constitutional Court and Judicial Commission).

The election of the head of state is a very urgent and vital issue for the existence of the state. However, Islam does not clearly regulate how the succession of leadership, resulting in divisions within Islam itself. Therefore, al-Mawardi as a medieval Islamic thinker formulated his idea of the election and appointment of the head of State. Therefore, al-Mawardi, the process of appointing the head of state can be done in two ways, first, by giving the mandate of the post of head of state to the crown prince or others (inheritance). This is based on the incarnation of Umar bin Khathab by Caliph Abu Bakr as head of state, secondly, elected by ahlul halli wal aqdi (voter council) appointed by the head of state. In this case Mawardi based his argument on the incident of Uthman bin Affan's appointment by a group of six members appointed by Caliph Umar. According to Mawardi, these two moments are a legal source that is believed to be the truth that can be used as the basis of electoral theory and the appointment of head of state.

Based on the above framework, finally this study explored the historical backgrounds that made the elections system were varied from Soekarno power to present condition. The law interpretations of the election of head of state in Indonesia and political situations affected the system of democracy that have been practiced in representative and popular vote models. 


\section{Research Methodology}

Qualitative descriptive approach was applied to seek the phenomenon holistically-contextually (intact according to the context) through the collection of data from a natural setting. Documentation method was carried out to find data about things or variables in the form of notes, transcripts, books, newspapers, magazines, inscriptions, and minutes of meetings, agenda and so forth. The next step was to record and classify data according to the type, both primary and secondary data. The data were analyzed by Content Analysis to describe objectively, systematically and quantitatively explicit content. Content analysis also was using secondary data source (Krickhoff 1995: 86).

\section{Findings}

In the period 1945-1959, the political configuration that emerged was a democratic political configuration in Indonesia. Political life in this period is characterized as a liberal democracy (Moeljatno 1988:7). In such a configuration, it appears that parties play a very dominant role in the process of formulating state policy through their constitutional (parliamentary) (Muhaemin 1990:43). Along with that, the executive branch is in an "inferior" position compared to the parties so that the government is always up and the political situation goes unstable. Freedom of the press, when compared with other periods, can be said to run well. In fact, in this period of liberal democracy the censorship and banning regulations that prevailed since the time of the Dutch East Indies were officially revoked.

Based on previous descriptions, the author sees that in the early stages of Soekarno's position as head of state, the structure of the state was relatively democratic. That is, the institutional structure of institutions seems relevant to political theories that are generally used in the context of the legal state (Rechstaat) which channels the parliamentary political system. In such a position, the state structure appears to be equivalent between the executive body (the Presidency) and the Legislative Agencies (MPR / Constituent Assembly / Central Indonesian National Committee (KNIP)). In fact, the political position of the MPR in the early days of President Sukarno seemed superior compared with the Presidential Institution.

The transition and the period of parliamentary democracy to guided democracy are marked by the change of power distribution map. Power becomes centralized in the hands of the president. The transition from the period of parliamentary democracy to guided democracy is marked by the changing distribution of power. Power became centralized to the president's hand, and was significantly offset by the roles and powers of the Communist Party of Indonesia (PKI) and the Army. This period is characterized by the high political mobilization on behalf of Sukarno's revolution. Sukarno himself became a central figure in the Circle of Power. Meanwhile, society experiences exile from power, though on the surface there is a great desire to participate in the revolution. The superstructure and political infrastructure are controlled almost fully by the president. And in this situation, the PKI used various means to build mass bases on a large scale in the framework of their long-term goals; Full control of political power and government. The PKI's great ambitions backfired not only for the PKI, but also, finally, for Sukarno. After the failed PKI coup at the end of September 1965, power quickly shifted toward a new map, so the New Order was born (Nasikun 1984 : 84-85).

Reviewing the state structure of 1945-1965 exposed above, the author may submit several important notes, among others:

1. The stability of the government within the span of 20 years is in a state of extreme concern. In Pinch and Lev noted, during 1945-1965 the Indonesian political system went through 25 cabinet turns and no cabinet could survive within 2 full years. The same picture was expressed by Hudson and Taylor. According to Hudson and Taylor Throughout 1948-1967 there have been 20 executive power changes in Indonesia, with an average of one turn every year (Nasikun 1984 :84-85).

2. Political stability in general is also alarming. This is, among other things, shown by the occurrence of political conflict in a very high quantity. According to Hudson and Taylor's records, during 1948-1967, there have been protests, riots, 7,900 times of armed attacks, and 
615,000 people killed for political violence. In general, ideological and primordial conflicts do experience its peak actualization in the 20 years post-independence language.

3. The economic crisis is another characteristic of the 1945-1965. In the period of parliamentary revolution and democracy, the continuous shift of power has caused every cabinet to not realize their economic and social programs. As a result, the economy is neglected. So it is with the period of guided democracy. The inclination of the revolution, excessive attention to international affairs, and mismanagement and political mismanagement has led to guided democracy experiencing severe economic crisis.

4. At the same time, the institutional political devices are in a state of apprehension too. Bureaucracy and other elements of government are in a state of neglect and decay. As a result, the political and government processes are stalled due to lack of preparedness and inability of the apparatus. These circumstances are what we can note as a result of the political struggle and democratic practice throughout 1945-1965.

Therefore, even though party life and political participation once occupied the golden age, but the effectiveness of government cannot be achieved impressively. Democracy, therefore, cannot be said to be well practiced in this period. Conversely, political conflict and stability are at the most egregious level Throughout Indonesia's history of independence. It was within this framework that the New Order was emerged.

Despite the fact that the democracy of the New Order Era was in reality only then applauded. The hope just patted the wind. Throughout the history of the New Order, writers can identify the existence of two different patterns of power distribution (Fatah 2000:22). The "first" pattern was formed during the early consolidation period of the New Order. At the time when the president had not emerged as an independent political force and was still collectivized within the Army or military forces, the second "Pattern" was soon formed after the Golkar (Single Majority Party) won two elections. The New Order's rulers had concrete and firm political legitimacy. The "third" pattern, the president slowly but surely emerges as an independent political force, and ultimately becomes the central power. Both on the first pattern especially and on the second pattern, the president play his role with the possession of great power. In these circumstances there was practically no effective political control over the New Order president, either within the circle of power of the state moreover and beyond that. The ineffectiveness of this control occurred either from formal institutions, namely legislative, as well as those coming from opposition groups. At the same time, the judicial institution practically does not play a substantial role of control, given its structural limitations.

\section{The election of head of state through the system directly (popular vote)}

The direct election of heads of state takes place in developed and democratic countries such as in the United States, and now it also has been practiced in Indonesia and elsewhere. The election of Head of State in Indonesia was directly by the people; one man one vote. Its weaknesses is the equalization of the quality and quantity of voice between men who has knowledge much like a professor with a pedicab driver. Whereas logically healthy the quality and influence between a professor with a pedicab driver is different and everyone agrees that a professor is much more powerful than a pedicab driver. Since a professor differs considerably from a pedicab driver in every way, then the sound of a professor should not be the same as the voice of a pedicab driver. It is this that becomes the greed of the direct election system using this one man one fote. Therefore it is necessary to find a solution so that there is justice in the case of a voice between a professor and a pedicab driver. The same applies to others in all professions that the community professionally pro- vides. If this is not done then still this kind of election model will not produce the ideal leader, desired by the community, including the people who pursue the field of scholarship.

Theoretically, the election system of the Head of State with the model of the direct election system is more democratic than the indirect or multi-level elections, either through the Electoral College or through a State institution. However, in that case, it should also be determined first how voting methods of voters, how the nominating mechanism of people who want to advance as head of State, and also how the election formulation. 
The direct election of head of state is one form of realization of the people's sovereignty. Moreover, in the understanding of people's sovereignty (democracy), it is the people who are regarded as owners and holders of supreme authority within a State. In the modern democratic system, legality and legitimacy of government is a very important factor because on the one hand a government must be based on legal and constitutional provisions so it is said to be legal, and on the other hand the government must also be legitimate or trusted. Therefore, the direct election of the head of state can be regarded as a manifestation of the people's sovereignty.

The regulation of the law in the 1945 Constitution of the State of the Republic of Indonesia should be based on the principle of law to make the sovereignty of the people should be more consistent. This is because systematically, the absolute rights of citizens as stated in Article 27 paragraph (1) and Article 28D paragraph (3) of the 1945 Constitution of the Republic of Indonesia are a formulation supporting the implementation of the concept of people's sovereignty. Therefore, in the election of the President and Vice President, the principle of people's sovereignty is naturally realized by direct election of President and Vice President by the people, although in the formulation of Article 6A as a whole, there is an indication that the principle of the people's sovereignty law is not fully guaranteed .

According to Indonesian Law, article 6A paragraph (2), it has been determined that the candidates for President and Vice President must get support from political parties and formally nominated by political parties, then the political parties form the political party alliances that can be done by more than two political parties. This opinion reinforces that the dominance of political parties in the matter of nominating the President and Vice President becomes a reality. A reduction in the number of political parties naturally. A political party has the sovereignty of the people has been assumed by political parties as a political force representing the people. In Article 6A paragraph (3) it has been determined that the candidate pairs of President and Vice President are said to be the winners if they win the most votes. In this case, an absolute majority principle or more than fifty percent of the vote with composition shall at least get twenty percent of the vote in more than half of the Province. This provision allows the elected President and Vice-President to have strong legitimacy, not only quantitatively through popular votes, but also with broad support from all parts of Indonesia. However, if there is no such winner, it is formulated as in paragraph (4).

\section{In the Reform Order Era}

The stepdown of Soeharto made B.J. Habibie on May 21 st, 1998 as new President of Indonesia. It is the bell of the end of the New Order Era changed the milestones of the Reform Era. Judging from the perspective of Constitutional Law, the procession of the Indonesian Presindential sucession from Gen Suharto to B J. Habibie, at the inauguration and taking of his oath on May 21, 1998, took contitutional law study to clarify this case. There are various cross-references that need to be studied further and deeper according to the format of Constitutional Law. It is intended to get more actual, factual, and concrete factual substances about the presidential replacement procession.

President Soeharto after the resignation speech was read out, the inauguration and taking of the oath of President B. J. Habibie was taken before the other state officials present at the time, and was done by the Chief Justice of the Supreme Court (Sarwata, S.H.). Then, after the inauguration, BJ.Habibie got congratulation from Soeharto and other high officials and left the Credential Room to the Room of Jepara to meet with the leader of legislators and people Assembly. After the inauguration of B J Habibie as a new president, General Wiranto stepped up to the microphone and gave a statement about Armed Forces of the Republic of Indonesia backed up the new president. Regardless and the statement of Arm Forces' attitude to the statement of Suharto's resignation, the issue here lies not in the substance of Article 8 of the 1945 Constitution in the context of Constitutional Law, but rather its association with all the other relevant legal norms relating thereto, in addition to the Constitutional Law and this long-standing public policy has been mistakenly applied by Soeharto during his presidency.

Suharto's resignation speech stirred controversial pro and contra. It is debated whether valid or not, constitutional or unconstitutional. Suharto's statement is legitimate and constitutional. This argument refers to the use of justification according to Article 8 of the 1945 Constitution which reads as follows: 
If the president dies or quits, or cannot perform his duties in his term of office, he will be replaced by the vice-president until expired.

The reason also refers to People Assemby Decision; TAP MPR No. VII MPR / 1973, Article 1 paragraph (2) which states as follows.

What is meant by absence to remain in this provision is death, termination, or unable to perform obligations in length of service.

In fact, the mechanisms on the substance of the articles mentioned above have been interpreted in an sich (mutatis mutandis) so that based on the understanding of Article 2, paragraphs (i), (2), and (3), MPR Decree VII / MPR / 1973, Habibie's oath should be taken before the House (vide: Article 9 of the 1945 Constitution). However, since May 21, 1998 was a national holiday, the oath was made before the Supreme Court, which was also not possible, and not in the state palace as justification. If enforced, it is unconstitutional, because it has come out of the existing MPR TAP Convention for that purpose [vide: Article 6 paragraph (2) 1 which reads as follows: "If the DPR for the purpose referred to in paragraph (1) of this article is unlikely to hold a meeting, Then the temporary positions of the President, swearing or pledging inn front of the Supreme Court".

Due to the urgency of holding the interim presidential position of B.J. Habibie succeeded Suharto was to keep the national leadership vacuum alone, rather than the legal vacuum that could endanger national stability. Thus, if the unconventional state of the art practice of President Soeharto was rejected by People Assembly, there would be a rebellion in Indonesia.

\section{Coclusions}

Law interpretations and dynamic of political conditions of Indonesi made the Presidetial System

Shifting many times:

1.Guided Democracy during Soekarno Power (1945-1968): The institutions of the state according to the 1945 Constitution can be distinguished from the active institutions, namely the executive institutions (President and Vice President) and the legislative and passive state institutions, namely the judicial authorities (Supreme Court, Constitutional Court and Judicial Commission).

2. Pancasila Democarcy of Soehator Power (1968-1998) : The collapse of the Old Order and the birth of the New Order at the end of 1965 marked the growth of hopes for improvements in social, economic and political conditions. In contrast, the accumulation and centralization of power that during the Old Order was so clearly constructed, it was hoped that a new face would soon change with the pluralism of power. With regard to such political conditions, democratization is expected to grow and materialize. Not just a political rhetoric of the New Order government was performing on the Indonesian political stage.

3.Reformation Era BJ Habibie (1998- 1999), Abudurrahman Wahid and Megawati (1999-2004). In the case of Reformation Era, the members of parlement elected president and vice after political parties endorsed candidates in Assembly meeting.

4.Direct Democracy -Popular Vote : Political parties endorsed candicates to Commission of General Election. It was in Soesilo Bambang Yudhoyono Power (2004-2014) and Joko Widodo (2014).

\section{References}

Amos, Abraham. 2005. Sistem Ketatanegaraan Indonesia, Raja Grafindo Persada, Jakarta. Fatah, Eep Saefullah. 2000. Penghianatan Demokrasi Ala Order Baru. Rosda Karya, Bandung. Kirckoof, Valery. 1995. Content Analysis. UI, Jakarta. Mas'oed, Mochtar. 1989, Ekonomi dan Struktur Politik Order Baru. LP3ES, Jakarta. Moeljarto. 1988. Beberapa Pokok Tentang Sistem Kepartaian di Indonesia, Sospol UGM, Yogyakarta. Muhaemin, Yahya. 1990. Bisnis dan Politik, Kebijaksanaan Ekonomi Indonesia, LP3ES, Jakarta. Nasikun. 1984. Sistem Sosial Indonesia, Rajawali Pers, Jakarta.

\section{B.Indonesian Laws}

Undang-undang Nomor 8 Tahun 2000 tentang Pemilu

Undang-undang Nomor 12 Tahun 2006 tentang Kewarganegaraan 
The Turkish Online Journal of Design, Art and Communication - TOJDAC

ISSN: 2146-5193, September 2018 Special Edition, p.939-945

Undang-undang Nomor 42 Tahun 2008 tentang Pilpres dan Wapres

Tap MPRS No. XXV/MPRS/1965

Putusan MK N0.11-17/PUU-1/2009 tentang Pengakuan atas Hak Pilih eks PKI 